\title{
Reservoir Characterization of Sand Units Penetrated by Four Wells in the Nigerian Sector of the Chad Basin and its Implication for Hydrocarbon Generation and Accumulation
}

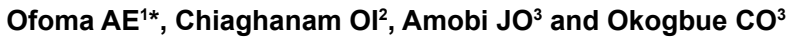

${ }^{1}$ Halliburton Energy Services (Landmark), Lagos, Nigeria

${ }^{2}$ Department of Geology, Anambra State University, Uli, Anambra State, Nigeria

${ }^{3}$ Department of Geology, University of Nigeria, Nsukka, Nigeria

\begin{abstract}
The reservoir properties of over six hundred sand units penetrated by four exploratory oil wells (Zy-01, Kt-01, Ks-01 \& Kd-01) in the Nigerian sector of the Chad Basin Northeastern Nigeria was carried out using the PRIZM GeoGraphix software. Results of the evaluation show that eighty-seven sand units have good reservoir properties for all the wells. Their sand thicknesses are between $-1 \mathrm{~m}$ and $-160 \mathrm{~m}$ while averages of effective $(\varphi \mathrm{E})$, density $(\varphi \mathrm{D})$ and sonic porosities $(\varphi S)$ are between $10 \& 41 \%, 10 \& 54 \%$ and $10 \& 89 \%$ respectively. These porosity results are fair to very good. Average shale volume content (Vshl) is between $23 \% \& 67 \%$, these values are beyond the acceptable limit in reservoirs. The averages of permeability (k) and fluid saturation (SwA \& Sh) are between 15md \& 7477.8md, $11 \% \& 71 \%$ and $29 \% \& 89 \%$ respectively. The permeability values are therefore moderate to excellent. Bulk volume water (BVW) is between $0.028 \& 0.188$, suggesting very fine to silty grained sands. A comparison of the values of apparent water resistivity (RwA) with water resistivity (Rw), suggest imprints of hydrocarbon in these sands. Also a further comparison of water saturation of flushed zone (SxO) with the Archie's water saturation (SwA), moveable hydrocarbon index (MHI) and moveable oil saturation (MOS) revealed possible hydrocarbon mobility in the flushed zone by invading drilling fluid. Calculated temperatures and pressures of the wells show increasing trend with depth. Geopressures were encountered at some shale beds within the wells. The sand units of the wells with the good reservoir properties correlate fairly well along Ks-01, Kt-01 \& Zy-01 wells. This study has shown that some of the sand units in the study wells have favourable reservoir properties that will enable the generation, accumulation and preservation of hydrocarbons, especially within Ks-01 and Zy-01 wells. However, the very high values obtained for Vshl requires that further estimation of SwA be carried out using other methods and models for a better understanding of the hydrocarbon potential of the Basin. Furthermore, drilling to deeper depths is strongly recommended due to the very favourable reservoir properties observed at deeper depths for $\mathrm{Ks}-01$ and Zy-01 wells respectively.
\end{abstract}

Keywords: Reservoir; Hydrocarbon; Porosity; Permeability; Water saturation; Lithology

\section{List of Abbreviations and Terms}

\section{Sp - Spontaneous potential}

GR - Gamma Ray

MSFL - Micro spherically focused log Rt - Archie-predicted true resistivity SwA

- Archie-derived water saturation Vshl - Shale Volume Content

md - millidarcy

SwMS - modified Simandox (1963) equation

Sw - Water Saturation

Sh - Hydrocarbon Saturation

Swr - saturation moveable hydrocarbon index

Rxo - flush zone resistivity

Rwa - apparent water resistivity

Ro - Resistivity of water filled formation

Swr - Ratio Water Saturation

$\mathrm{Rw}$ - water resistivity

$\mathrm{SxO}$ - Water saturation of the flushed zone $\mathrm{MHI}$ - moveable hydrocarbon index (MHI) v/v - Volume/Volume

MOS - moveable oil saturation

ROS - hydrocarbon saturation

$\mathrm{Rmf}$ - resistivity of mud filtrate (Rmf) SN - short normal log

ILD - Deep Induction Resistivity log

TD - total depth KB - Kelly bushing $\mathrm{k}$ - Permeability

PHID or $(\varphi D)$ - Density Porosity PHIS or $(\varphi S)$ - Sonic Porosity PHIAVE -

Average Porosity

PHIE or $(\varphi \mathrm{E})$ - Effective Porosity
PHIR - Resistivity derived Porosity

DiffCal - Differential Calliper

Temp - Temperature

PRES - Pressure

\section{Introduction}

To achieve successful hydrocarbon exploration and production targets in the inland Basins of Nigeria requires that detailed and systematic studies and analyses of available geoscientific data be heightened. Recently the Nigerian National Petroleum Corporation (NNPC) launched a renewed effort to acquire additional data and carryout further exploration work on the Nigerian end of the Chad Basin based on the reports of the discovery of hydrocarbons on the other side of the structurally related contiguous Chad Basin in Cameroon, Chad and the Niger republic. Crude oil search began in the Nigerian sector

*Corresponding author: Ofoma AE, Halliburton Energy Services (Landmark), Lagos, Nigeria, Tel: +234(0)8033314470; E-mail: porasino@yahoo.com

Received August 22, 2014; Accepted October 20, 2014; Published October 22, 2014

Citation: Ofoma AE, Chiaghanam OI, Amobi JO, Okogbue CO (2014) Reservoir Characterization of Sand Units Penetrated by Four Wells in the Nigerian Sector of the Chad Basin and its Implication for Hydrocarbon Generation and Accumulation. J Geol Geosci 3: 183. doi:10.4172/2329-6755.1000183

Copyright: (c) 2014 Ofoma AE, et al. This is an open-access article distributed under the terms of the Creative Commons Attribution License, which permits unrestricted use, distribution, and reproduction in any medium, provided the original author and source are credited. 


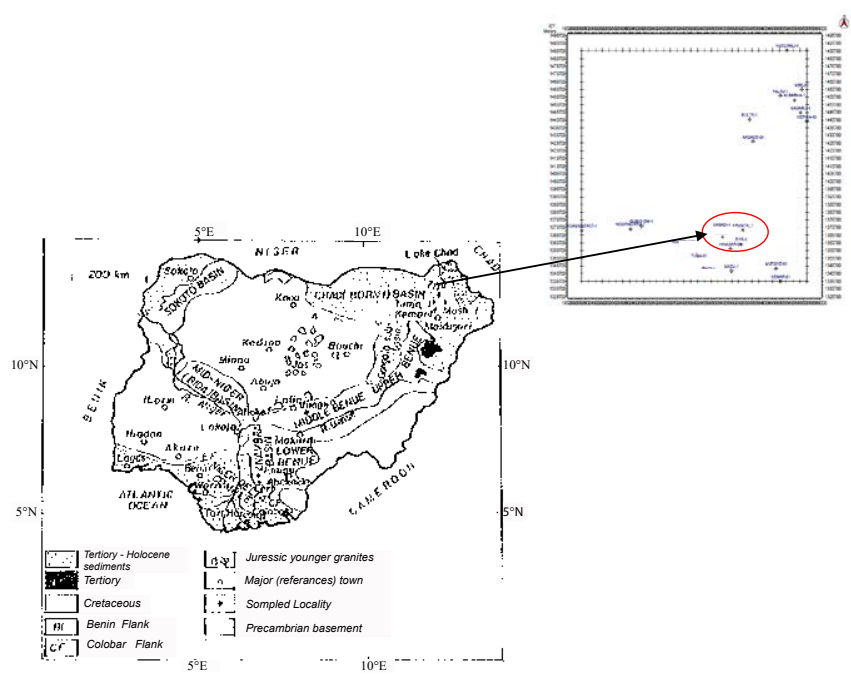

Figure 1: Geologic map of Nigeria showing the Chad Basin and the base map of the Basin showing the study wells

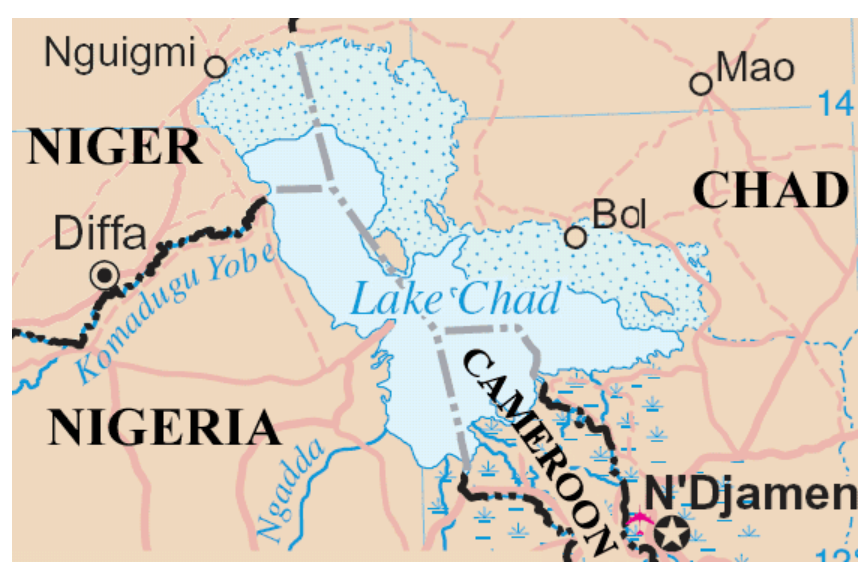

Figure 2: Red broken arrows used to encircle the Chad Basin and the countries where the Basin can be found.

of the Chad Basin in 1976 with about twenty-three (23) exploratory oil wells drilled and 2D seismic data acquired in the area. However, due to the very poor and non-commercial discovery of oil \& gas in the Basin, interest for further search dwindled. This interest has once again rekindled due to the recent commercial discovery of oil \& gas in nearby countries where the Basin extends. Any potential discovery will add to the nation's proven reserves asset which is put at $35 \mathrm{bbl}$ for oil and 170 tscf for gas [1]. Many scholars such as Avbovbo et al., Olugbemiro et al., Okosun, Gazali and Zarma, Christopher, Obaje et al., Nwankwo et al., Nwankwo and Ekine [2-8] have separately carried out different geoscientific studies on the Chad Basin of Northeastern Nigeria and their findings have largely been in favour of possible presence of hydrocarbons in the Chad Basin.

This study, therefore, $\mathrm{x}$-rays the reservoir properties of sand units penetrated by four wells in the Nigerian end of the Chad Basin with a view to ascertaining if those properties are good enough to support hydrocarbon generation, preservation and accumulation. About twenty-eight log curves from four exploratory oil wells ks-01, Kt-01, Zy-01 \& Kd-01 (Figure 1) drilled in the Nigerian end of the Chad
Basin were used for this evaluation. The log data are digitized in ASCII format at $0.125 \mathrm{~m}$ intervals. Reservoir properties characterizations are useful models of reservoirs that are pertinent to the knowledge of the ability of the reservoir to store and transmit hydrocarbons. They are also useful in simulating the behavior of the fluids within the reservoirs under different sets of circumstance and to find the optimal production techniques that will maximize production [9].

\section{Geologic Setting}

The Chad Basin is a large intracratonic Basin in central West Africa and one-tenth (about 21\%) of its surface area lies in Northeastern Nigeria (Figure 1). It covers an area of approximately 2,500,000 $\mathrm{km}^{2}[8]$ extending over portions of Niger Republic, Chad, Sudan and Northern parts of Cameroon and Nigeria (Figure 2). The origin of the Chad Basin is believed to be related to a series of Cretaceous and later rift system in central and West Africa that expanded during the separation of the African and South American plates [1,7]. Pre-Santonian Cretaceous sediments were deposited within the rift system. The Nigerian end of the Chad Basin lies between latitudes $110 \mathrm{~N} \& 140 \mathrm{~N}$ and longitudes $90 \mathrm{E}$ \& 140E, covering Borno, parts of Yobe and Jigawa states of Nigeria [10]. Sediment thickness in the Basin is believed to be more than 4.650 $\mathrm{km}$ and comprises marine and continental deposits made up from the oldest; the Bima Sandstone which is sparsely fossiliferous, poorly sorted and medium to coarse grained, a transitional calcareous Gongila Formation, Fika Shale, Kerri Kerri and Chad Formations in that order (Table 1). Also commonly occurring are crystalline rocks of granite, gneisses, mica schists, basalts and minor basic and acidic intrusives [8].

\section{Methodology}

The digital log data used for this study included the gamma ray, caliper, density, sonic and resistivity logs. The requisite environmental corrections were applied to the logs and the formulas below were inputted into the user define equation (UDE) of the PRIZM GeoGraphix software and used for the evaluation.

\section{a. Density Porosity}

PHID [] $=($ RhoM - RHOB []) / (RhoM - RhoF $)$

b. Sonic Porosity (Wyllie); Enter Compaction Coefficient below, $\mathrm{Cmp}=1.0$

$$
\text { PHIS[] }=(1 / \mathrm{Cmp})^{\star}(\mathrm{DT}[]-\mathrm{DTma}) /(\text { DTfld }- \text { DTma })
$$

c. Average Porosity from Density Porosity and Sonic Porosity PHIAVE[] $=($ PHID []$+$ PHIS[] $) / 2$

d. Shale volume content

$\operatorname{Vshl}[]=\min (1, \max (0,($ GR []$-G R c l n) /($ GRshl-GRcln $)))$

e. Effective Porosity

\begin{tabular}{|c|c|c|}
\hline Age & Formation & Depth (m) \\
\hline $\begin{array}{c}\text { Pliestocene-Miocene } \\
(23.5-84.0 \mathrm{Ma})\end{array}$ & Chad Formation & 800 \\
\hline $\begin{array}{c}\text { Coniacian - Santonian } \\
(84.0-91.1 \mathrm{Ma})\end{array}$ & Fika Shales & 1800 \\
\hline $\begin{array}{c}\text { Turonian } \\
(84.0-91.1 \mathrm{Ma})\end{array}$ & Gongila Formation & 2350 \\
\hline $\begin{array}{c}\text { Albian - Cenomanian } \\
(97.0-110 \mathrm{Ma})\end{array}$ & Bima Sandstone & 5000 \\
\hline
\end{tabular}

Table 1: Generalized well lithology for the Nigerian sector of the Chad Basin (Adapted from Nwankwo et al., [7]). 
Citation: Ofoma AE, Chiaghanam OI, Amobi JO, Okogbue CO (2014) Reservoir Characterization of Sand Units Penetrated by Four Wells in the Nigerian Sector of the Chad Basin and its Implication for Hydrocarbon Generation and Accumulation. J Geol Geosci 3: 183. doi:10.4172/23296755.1000183

Page 3 of 9

$$
\text { PHIE[ }]=\text { PHIAVE[ }]^{*}(1-\mathrm{Vshl}[])
$$

f. Resistivity Derived Porosity

$$
\text { PHIR[] }=\mathrm{a}^{\star} \mathrm{Rw} / \mathrm{ILD}[]^{\wedge} \mathrm{m}
$$

g. True Resistivity

$\operatorname{Rt}[]=1.67 * \operatorname{ILD}[]-0.67 * \mathrm{SN}[]$

h. Archie Water Saturation

$\operatorname{SwA}[]=\left(\mathrm{a}^{\star} \mathrm{Rw} /\left(\operatorname{ILD}[]^{\star} \operatorname{PHIAVE}[]^{\wedge} \mathrm{m}\right)\right)^{\wedge}(1 / \mathrm{n})$

Modified Simandoux SwMS; Requires, PhiE[], Vshl[] \& RT[] If $(\operatorname{Vshl}[]<1)$

SwMS[] $=\left(\operatorname{sqrt}\left(\quad(\operatorname{Vshl}[] / R s h l) \wedge 2+4^{\star} \mathrm{PHIE}[]^{\wedge} \mathrm{m} /\left(\mathrm{a}^{*} \mathrm{Rw}^{\star}(1-\right.\right.\right.$ $\left.\left.\left.\mathrm{Vshl}[])^{\star} \mathrm{RT}[]\right)\right)-\mathrm{Vshl}[] / \mathrm{Rshl}\right) /\left(2^{\star} \mathrm{PHIE}[]^{\wedge} \mathrm{m} /\left(\mathrm{a}^{\star} \mathrm{Rw}^{\star}(1-\mathrm{Vshl}[])\right)\right)$ Else SwMS[] $=1$ End If

i. Water Saturation of the Flushed Zone

$\mathrm{SxO}[]=\left(\mathrm{a}^{\star} \mathrm{Rmf} /\left(\mathrm{SN}[]^{\star} \mathrm{PHIAVE}[]^{\wedge} \mathrm{m}\right)\right)^{\wedge}(1 / \mathrm{n})$

j. Apparent Water Resistivity

$\mathrm{Rwa}[]=\mathrm{ILD}[]^{*} \mathrm{PHIAVE}[]^{\wedge} \mathrm{m}$

k. Hydrocarbon Saturation

$\operatorname{Sh}[]=(1-\operatorname{SwMS}[])$

1. Moveable Hydrocarbon Index

$\mathrm{MHI}[]=(\mathrm{SwMS}[] / \mathrm{SxO}[])$

m. Residual Oil Saturation

$\mathrm{ROS}[]=1.0-\mathrm{SxO}[]$

n. Moveable Oil Saturation

$\operatorname{MOS}[]=\mathrm{SxO}[]-\mathrm{SwMS}[]$

o. Resistivity of Water filled formation

$\mathrm{Ro}[]=\mathrm{a}^{\star} \mathrm{Rw} / \mathrm{PHIAVE}[]^{\wedge} \mathrm{m}$

p. Ratio Water Saturation

Swr[] $=(\mathrm{SN}[] / \mathrm{ILD}[] /(\mathrm{Rmf} / \mathrm{Rw}))^{\wedge} 0.625$

q. Differential Caliper

DiffCal []$=$ CALI []$-$ Bit Size

r. Pay Flag with Porosity and Water Saturation Cutoffs

Pay[] $=$ PHIAVE[ $>>$ PhiCutoff and SwMS[] $<$ SwCutoff

s. Hydrocarbon Pore Thickness if Pay Exists

If $($ Pay[]) Then HydPhiTh[] $=(1-$ SwMS[] $) *$ PHIAVE[] * $<$ Step $>$ Else HydPhiTh[] $=0$

t. Bulk Volume Water

BVW []$=$ PHIAVE[ $]$ * SwMS[]

u. Hydrocarbon Pore Volume

SoPhiH []$=(1-$ SwMS []$) *$ PHIAVE []$*<$ Step $>$

v. Timur Permeability

$\mathrm{K}[]=\left(100 * \mathrm{PHIE}[]^{\wedge} 2.25 / \text { SwIrr }\right)^{\wedge} 2$

w. Environmental corrections of Temp \& PRES Temperature 'C;
Degrees C \& Depth in Meters

Temp []$=17.5+.02 \star$ DEPTH[ $]$

x. resssure in .Mpa, Mudwt in kg/m3, Depth in Meters

PRES[] $=$ Mudwt ${ }^{*}$ DEPTH[] $/ 102000$

The results generated from the evaluation were thereafter posted as signatures or wiggles on the PRIZM display. The quality control/ assurance (QC/QA) measures taken to minimize errors were the comparison of the results obtained using the software with those obtained from both formulae and charts. The results obtained from the software agreed closely with those obtained from formulae and charts.

\section{Results and Discussion}

The log packages run for the study wells are partially complete. For instance the Sp, MSFL, neutron and dip-meter logs are not available. Visual examination of the gamma ray log curves for the study wells show a fairly constant low to moderate values through most of the sand units, indicating that the sands are somewhat shaly. Also, gamma ray signatures of the sands have predominantly cylindrical and serrated shapes, suggesting probably braided fluvial type environment, distributory channel-fill, submarine canyon-fill, evaporate fill, distal deep marine slope and/or carbonate shelf margin depositional environment $[11,12]$. The resistivity readings are moderate to high in some sand intervals and show evidence of invasion. The caliper curves show evidence of mudcake on the walls of the porous and permeable sands for all the wells. This is based on the results obtained from differential caliper estimation which are conspicuously negative. The caliper logs also show relatively constant hole diameter and no significant differential enlargement. Consistency of hole diameter indicates that $\log$ measurements are reliable. The digitized and interpreted log curves for some of the sand units of the four wells is presented in Figures 3 and 4, while the coordinates, total depth (TD), Kelly bushing (KB), elevation $(\mathrm{m})$ and spud date for the study wells (Zy-01, Kt-01, Ks-01 \& Kd-01) is contained in Table 2. More than six hundred sand units were delineated from the study wells, and their reservoir properties determined.

About eighty-seven (87) of these sand units were observed to be of good quality (Appendices 1-4). Their thicknesses range between $-1 \mathrm{~m}$ and $-160 \mathrm{~m}$ and show some significant amount of shale inter-fingering. The stacked bar plots (Figure 5) for the average shale/sand volume in percentages show that shale volume content for most of the sand units of the four wells are greater than $10 \%$. The acceptable value of less than $10 \%$ in reservoir sands has been proposed by Hilchie [13]. The results show average Vshl of between $23 \%$ \& $67 \%$ for all the wells. These abnormally high values of shale content in the sands of the Chad Basin can adversely affect the determination of in-place hydrocarbon volume, prediction of reservoir production rate(s), estimation of effective porosities, permeability and Archie-predicted true resistivity (Rt). Also, in shaly sands, where shales and clays contribute to electrical conductivity, Archie- derived water saturation (SwA) is sometimes pessimistic. However, the modified [14] equation for evaluating Sw in shaly reservoirs was used as an alternative to the Archies equation. Other estimations for porosity and permeability were equally compensated for the effect of the shales in the sands [15]. The scatter plot of Vshl against gamma ray log reading for the sand units of the wells (Figure 6) correlate reasonable well with each other. A direct relationship exists between the plotted Vshl and the gamma ray log reading for the sands. The gamma ray log readings for the sands did not exceed 90API and 
Citation: Ofoma AE, Chiaghanam OI, Amobi JO, Okogbue CO (2014) Reservoir Characterization of Sand Units Penetrated by Four Wells in the Nigerian Sector of the Chad Basin and its Implication for Hydrocarbon Generation and Accumulation. J Geol Geosci 3: 183. doi:10.4172/23296755.1000183

Page 4 of 9
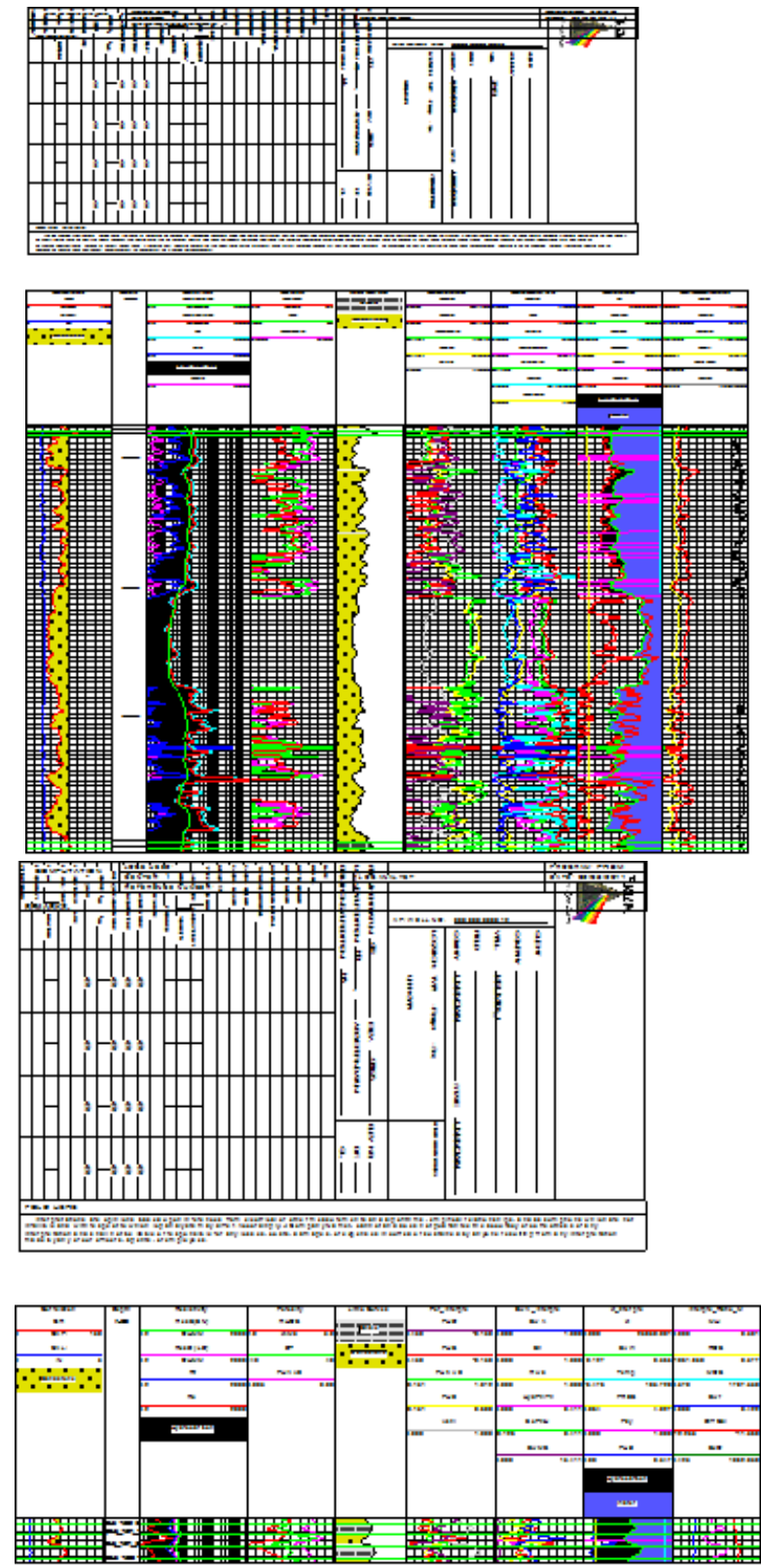

Figure 3: Log curves for sand unit 78 (Zy-01) well and sand unit $121(\mathrm{Kt}-01)$ well.

calculated Vshl is up to $70 \%$. Calculated Vshl greater than $100 \%$ are spurious and may be related to poor logs $[9,16]$.

The density and sonic log readings were used to estimate porosity. Column plots of average effective, density and sonic porosities against depth (Figures 7-9) for the sands of the wells are fair to very good for hydrocarbon accumulation $[9,17,18]$. Further investigations on the porosities of the sands have revealed for instance in Ks-01 well that the deeper (>2900 m) sand units have good to very good porosity indices. Plots of porosity versus depth (Figure 10) for all the wells show that porosity decreases with depth and also varies with lithology $[19,20]$. Negative density porosity values were observed in some of the wells indicating probably the presence of anhydrites or other forms of heavy minerals [21]. This may be true if we consider the geology of the area which is characterised by basement rocks. The scatter plot of density porosity against sonic porosity for the sand units (Figure 11) revealed dispersed points and also showed that density porosities are much less than the sonic porosities, the difference in the result of these two components may probably signify fractures [22]. This is further corroborated by the low density log readings and higher porosity values than the sonic log readings observed on the log display (Figures 12 and 13).

Permeability values is between $15 \mathrm{md} \& 7477.8 \mathrm{md}$ for the sand units of the study wells (Figure 14) and are therefore moderate to excellent for hydrocarbon production [23]. The Permeability values for Ks-01 \& Zy01 wells at deeper depths $(>2500 \mathrm{~m})$ show predominantly good to very
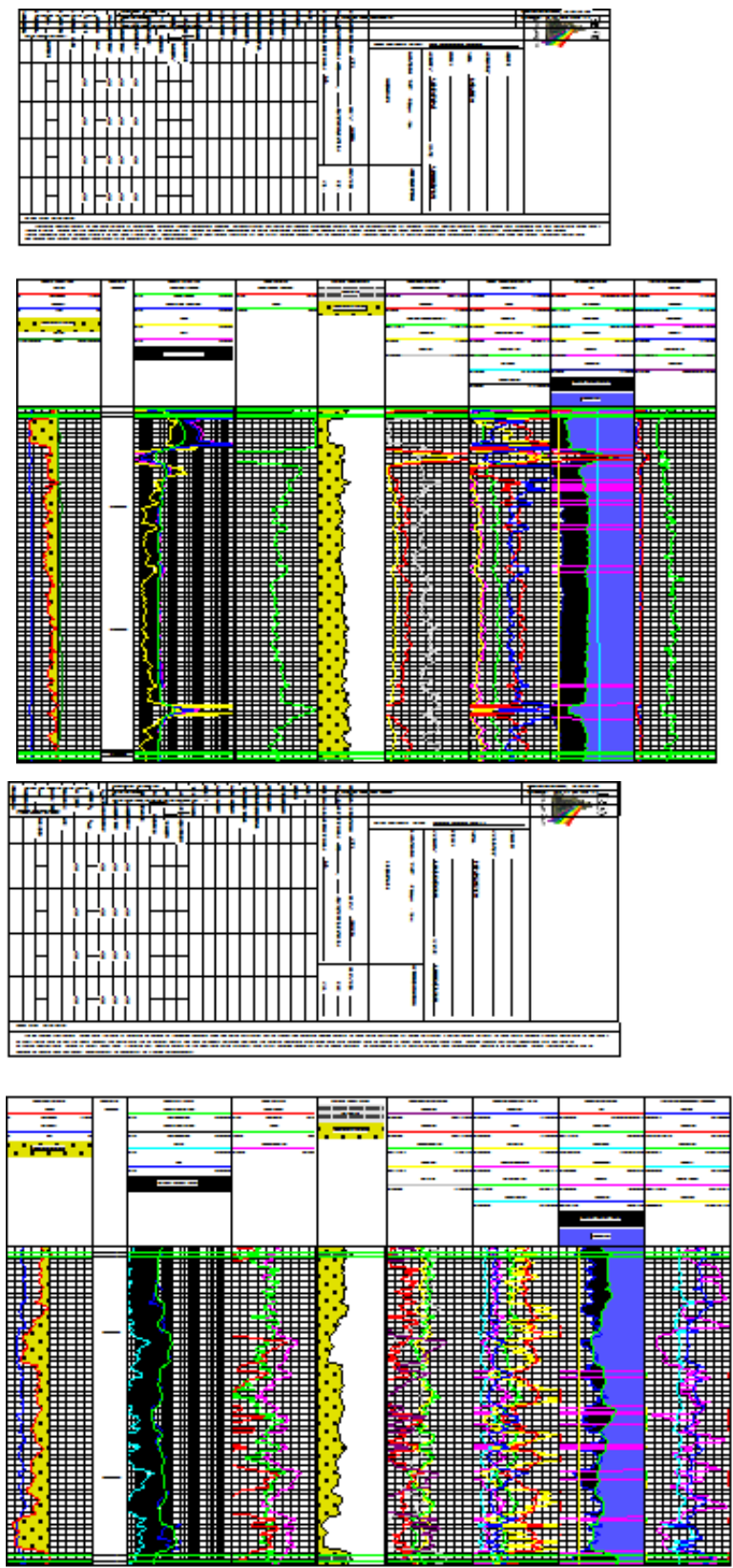

Figure 4: Log curves for sand unit 68 (Kd-01) well and sand unit 107 (Ks-01) well. 
Citation: Ofoma AE, Chiaghanam OI, Amobi JO, Okogbue CO (2014) Reservoir Characterization of Sand Units Penetrated by Four Wells in the Nigerian Sector of the Chad Basin and its Implication for Hydrocarbon Generation and Accumulation. J Geol Geosci 3: 183. doi:10.4172/23296755.1000183

Page 5 of 9

\begin{tabular}{|c|c|c|c|c|c|}
\hline $\begin{array}{l}\text { SN/ } \\
\text { Wells }\end{array}$ & Coordinates & $\begin{array}{l}\text { Total } \\
\text { Depth } \\
\text { (m) }\end{array}$ & $\begin{array}{l}\text { Kelly } \\
\text { Bushing } \\
\text { (K.B) (m) }\end{array}$ & $\begin{array}{l}\text { Elevation } \\
(\mathrm{m})\end{array}$ & $\begin{array}{l}\text { Spud } \\
\text { date }\end{array}$ \\
\hline $\begin{array}{l}1-Z y- \\
01\end{array}$ & $\begin{array}{l}\text { E or X: } 321924.600000 \text { (Longitude); } \\
\mathrm{N} \text { or Y: } 1362806.100000 \text { (Latitude) }\end{array}$ & 3375 & 303.7 & 295 & $\begin{array}{l}\text { Jan., } \\
1997\end{array}$ \\
\hline $\begin{array}{l}2-\mathrm{Kt}- \\
01\end{array}$ & $\begin{array}{l}\text { E or } X: 323251.030000 \text { (Longitude); } \\
\mathrm{N} \text { or Y: } 1372072.100000 \text { (Latitude) }\end{array}$ & 2950 & 299.52 & 291 & $\begin{array}{l}\text { Dec., } \\
1988\end{array}$ \\
\hline $\begin{array}{l}3-\mathrm{Kd}- \\
01\end{array}$ & $\begin{array}{l}\text { E or } X: 307750.000000 \text { (Longitude); } \\
\mathrm{N} \text { or } \mathrm{Y}: 1372500.000000 \text { (Latitude) }\end{array}$ & 3050 & 306.45 & 298 & $\begin{array}{l}\text { Dec., } \\
1985\end{array}$ \\
\hline $\begin{array}{l}4-\mathrm{Ks}- \\
01\end{array}$ & $\begin{array}{l}\text { E or } X: 314088.400000 \text { (Longitude); } \\
\mathrm{N} \text { or } \mathrm{Y}: 1359838.500000 \text { (Latitude) }\end{array}$ & 4665 & 303.7 & 295 & $\begin{array}{l}\text { Apr., } \\
1986\end{array}$ \\
\hline
\end{tabular}

Table 2: Showing the Coordinates, Total depth $(\mathrm{m}), \mathrm{K} . \mathrm{B}$, Elevation $(\mathrm{m})$ and Spud date for the study wells.

good indices (Figure 15). Scatter plots of permeability against porosity (Figure 16) show exponential increases in the plotted points and can be characterized as lying along the same general porosity-permeability trend. Also very few plotted points show slightly higher porosity and low permeability, suggesting probably early concentration by illitic clay prior to burial [16]. The average Archie's water saturation (SwA) and hydrocarbon saturation (Sh) is $11 \& 71 \%$ and $29 \& 89 \%$ respectively. Due to the shaly nature of the sands, the modified Simandox (1963) equation (SwMS) for evaluating Sw in shaly sands was employed. Average SwMS is between $5 \& 72 \%$ and its Sh is between $28 \& 95 \%$. It is observed that some of the sand units are hydrocarbon bearing and some are water bearing. The average values of SwA and SwMS for the sand units of the study wells were observed to be greater than the average values of water saturation moveable hydrocarbon index (Swr) suggesting that the flush zone resistivity (Rxo) is too low because invasion is very shallow. Therefore, the SwA and SwMS are considered a good value for the zones actual water saturation estimation.

The average values of apparent water resistivity (Rwa) are greater than the average values of water resistivity $(\mathrm{Rw})$, indicating probably presence of hydrocarbon in some of the sands of the study wells. Water saturation of the flushed zone $(\mathrm{SxO})$ was used as an indicator of hydrocarbon mobility. For most of the sands in the study wells $\mathrm{SxO}$ values are much greater than the Archie's water saturation values (SwA) and the modified Simandox water saturation (SwMS) values, implying that probably hydrocarbons in the flushed zone have been moved by invading drilling fluids [24]. A further evidence to show that hydrocarbon mobility occurred in the sands of the wells was the use of the moveable hydrocarbon index (MHI) which showed values of less than $0.7 \mathrm{v} / \mathrm{v}$ for most of the sands in the study wells. Asquith and Krygowski [24] have also suggested that values of MHI equal or greater than 1.0 indicate that hydrocarbons were not moved whereas $\mathrm{MHI}$ less than $0.7 \mathrm{v} / \mathrm{v}$ for sandstone indicates that hydrocarbon has been moved especially in a formation with good porosity and permeability. The average values of moveable oil saturation (MOS) are slightly high, (b/w $0.3 \& 2.7 \mathrm{v} / \mathrm{v}$ ) signalling another evidence of hydrocarbon mobility in the formation. The averages of residual hydrocarbon saturation (ROS) are negative. This result is quite disturbing if we consider the good results obtained for MHI and MOS. ROS is expected to be low atleast less than $0.7 \mathrm{v} / \mathrm{v}$ to show evidence of hydrocarbon mobility. Two reasons are considered for the negative results for ROS, either that the values of the resistivity of mud filtrate (Rmf) used as input parameter to generate the $\mathrm{SxO}$ is not correct and/or the use of the short normal (SN) $\log$ resistivity readings as flush zone resistivity $(\mathrm{RxO})$ instead of the log reading of the microspherically focused logs (MSFL) which was not available. Although, SN can be used in the absence of MSFL, it tends to read fluid resistivity that is a mix of Rw and Rmf especially if the formation were invaded. The latter reason is most likely the problem for the negative values for ROS.

The correlation of the subsurface sands of Ks-01, Kt-01 and Zy-01 wells (Figure 17) broadly define an anticlinal geometry at deeper depths. Sands at shallower depth tend to flatten out. The correlation also shows

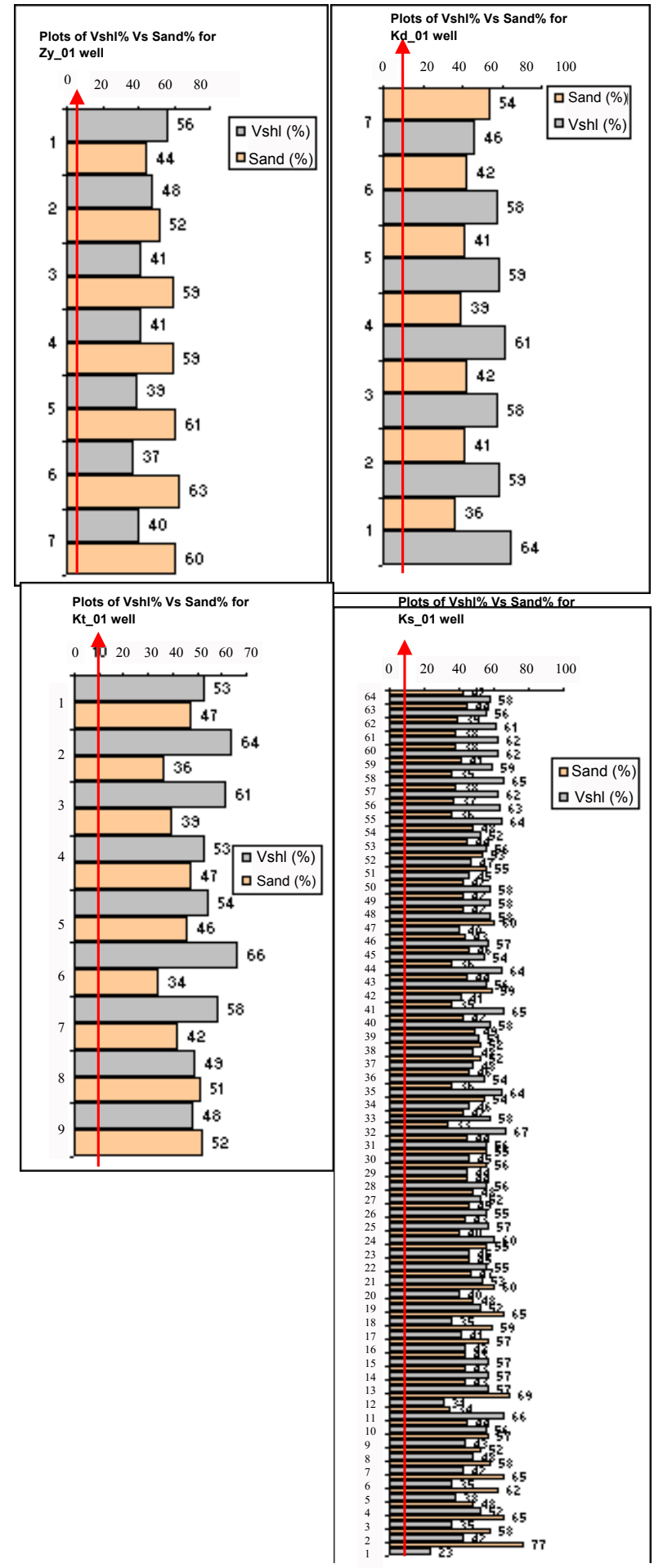

Figure 5: Stacked bar plot of Vshl (\%) Vs Sand (\%) for sand units of the study wells. 
Citation: Ofoma AE, Chiaghanam OI, Amobi JO, Okogbue CO (2014) Reservoir Characterization of Sand Units Penetrated by Four Wells in the Nigerian Sector of the Chad Basin and its Implication for Hydrocarbon Generation and Accumulation. J Geol Geosci 3: 183. doi:10.4172/23296755.1000183

Page 6 of 9

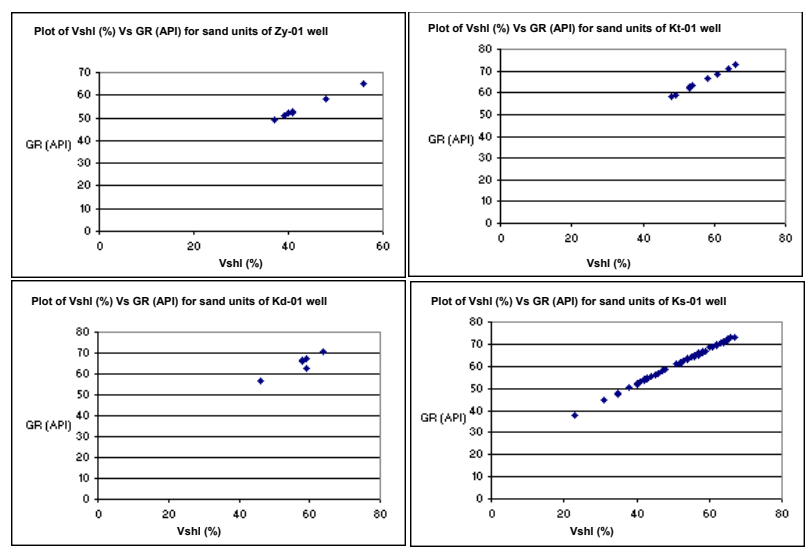

Figure 6: Plots of Vshl (\%) Vs GR (API) for sand units of the study wells.

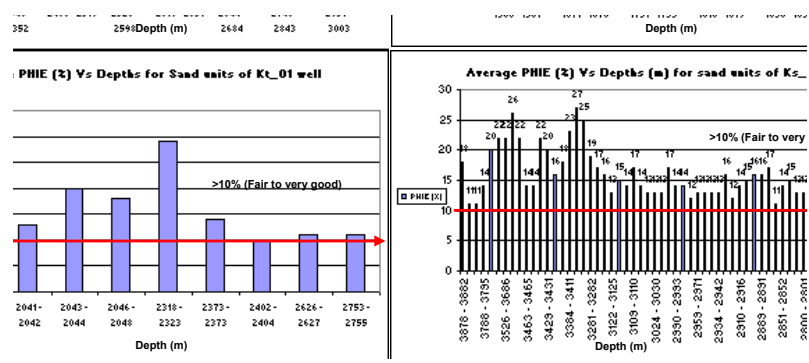

Figure 7: Column plot of PHIE (\%) Vs Depths $(m)$ for sand units of the study wells.

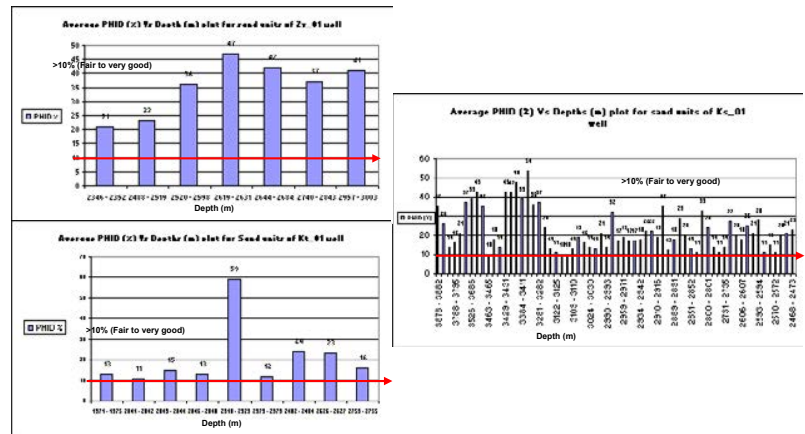

Figure 8: Column plot of PHID (\%) Vs Depths (m) for sand units of the study wells.

that the sands are continuous within the wells. This is evident from the similar gamma ray log signatures found in all the wells. Thicker sand bodies are observable within Ks-01 well relative to the other two wells. Lateral pinch-out and juxtaposition of the sands is observed more at the deeper parts of the wells. The suspected pinch-out may support a case for stratigraphic traps in the Basin and the juxtaposed sands may have provided drainage for generated hydrocarbons to migrate. It is also possible that the juxtaposed sands in the deeper sections of the wells is the outcome of post Santonian effects [25].

\section{Implications of the results for hydrocarbon generation and preservation in the Basin}

The three most essential elements of reservoir properties are porosity, permeability and fluid saturation. The overall average porosity and permeability values of the sand units with the good reservoir properties for the four wells (Kd-01, Ks-01, Kt-01 and Zy01) are within limits that are required for hydrocarbon generation,

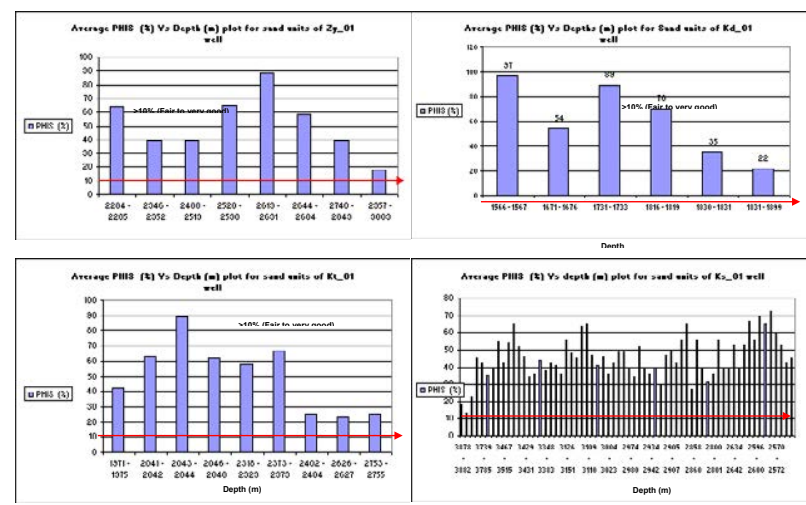

Figure 9: Column plot of PHIS (\%) Vs Depths $(m)$ for sand units of the study wells.

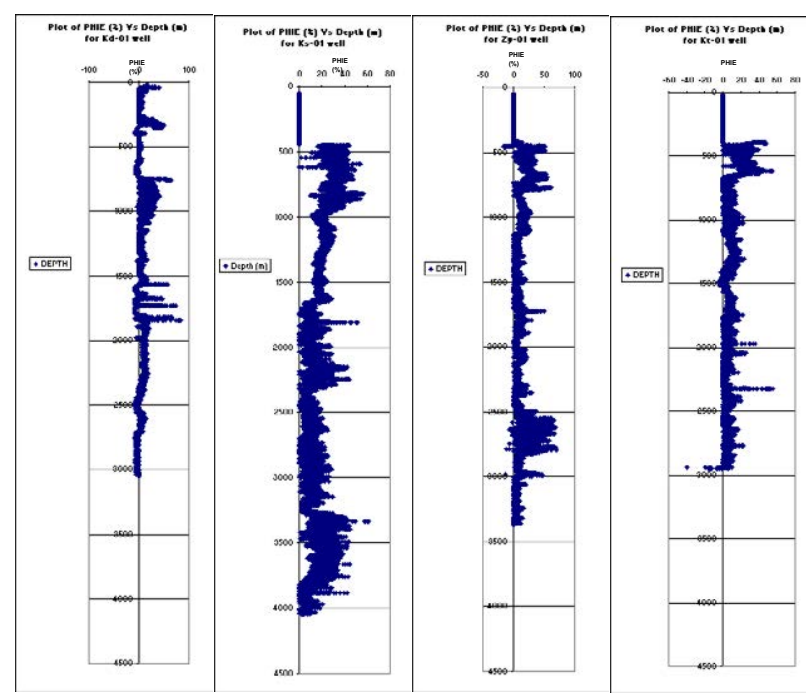

Figure 10: Plots of porosity against depth for all the study wells.

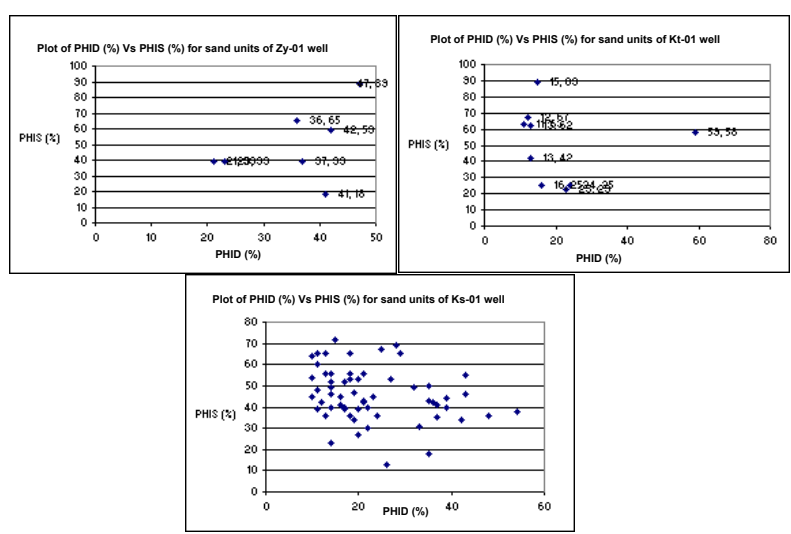

Figure 11: Plots of PHID (\%) Vs PHIS (\%) for sand units of the study wells. 
Citation: Ofoma AE, Chiaghanam OI, Amobi JO, Okogbue CO (2014) Reservoir Characterization of Sand Units Penetrated by Four Wells in the Nigerian Sector of the Chad Basin and its Implication for Hydrocarbon Generation and Accumulation. J Geol Geosci 3: 183. doi:10.4172/23296755.1000183

Page 7 of 9
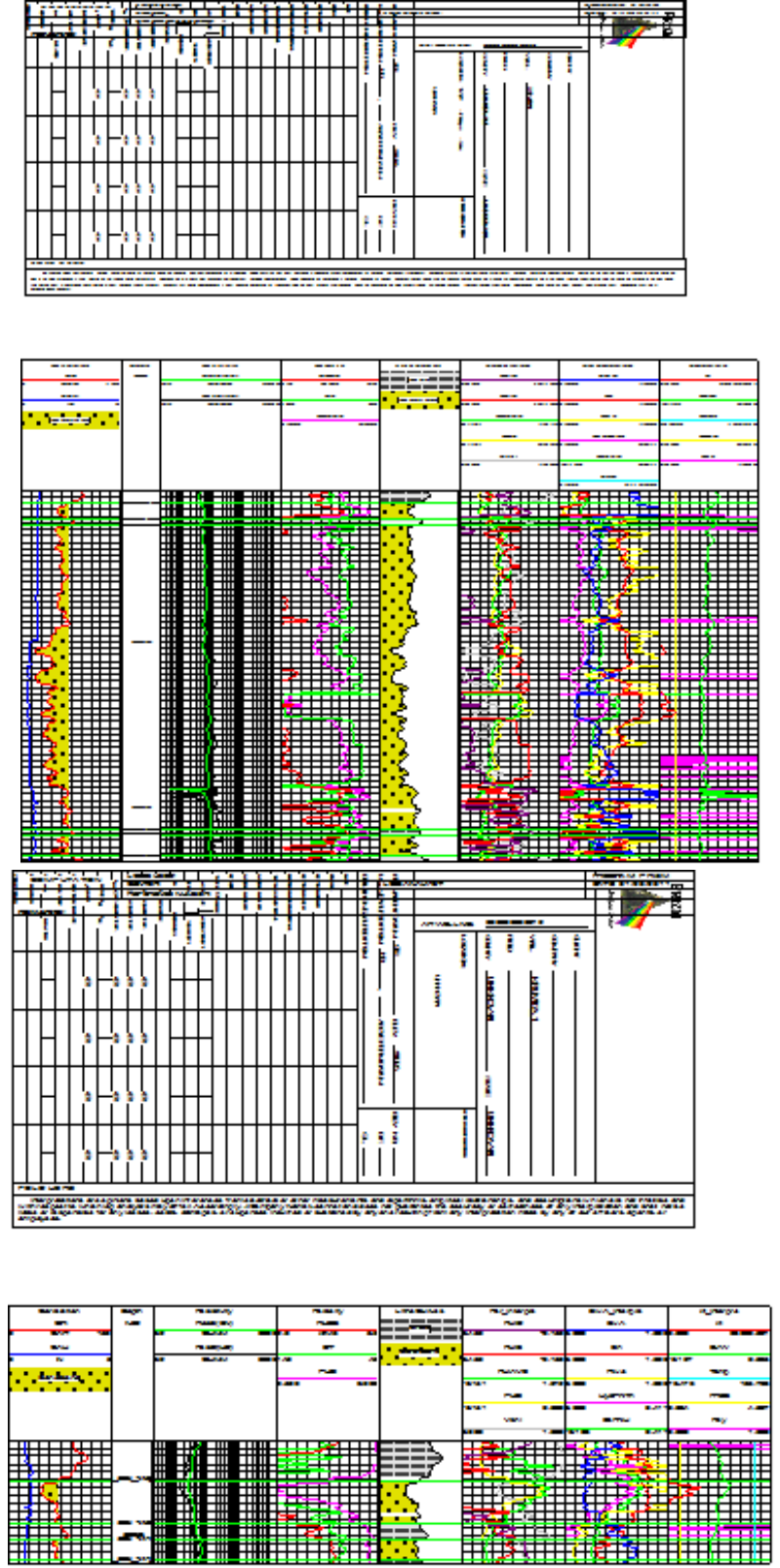

Figure 12: Identified fractures on some of the sand units (sand unit 60 for Zy01 and sand unit 142 for Kt01 wells). This was done by plotting the bulk density and sonic logs on a compatible porosity scale.

accumulation and preservation. The predominantly fair permeability results, if we consider the entire evaluation, are perhaps as a result of the silty nature of the sands. The results further show that sediments within deeper depths have better reservoir properties relative to the shallower parts. Correlation of the wells has revealed that sands within Ks-01 well are thicker and better developed. Also, sands within the deeper parts of the Basin are somewhat juxtaposed suggesting probably block faulting and post Santonian effects. The juxtaposed nature of the sands may have provided avenue for the drainage of generated hydrocarbons. Stratigraphic traps are also suggested in the Basin in addition to other trapping mechanisms based on the observed pinchout of the sands. Further studies on this using seismic data, velocity track analysis (VTA), ground water simulation method and differential interformational velocity analysis (DIVA) is advocated. MHI and MOS have revealed hydrocarbon mobility in the sands of the wells, although, commercial discovery of hydrocarbons is yet to be made in the Basin. Further analysis on the Basin using 2D/3D seismic data is suggested.

\section{Conclusion}

The digital log data used for this study were evaluated using the PRIZM GeoGraphix software, a windows based geology and geophysics (G\&G) software. On the strength of the evaluations, the following summary and conclusions are deduced:

(1) Eighty-seven (87) sand units with good reservoir properties were delineated and their thicknesses range between $-1 \mathrm{~m}$ and $-160 \mathrm{~m}$

(2) Shale volume content in the sand units is abnormally high and may give incorrect results for in- place hydrocarbon volume and reservoir production rates. It may also cause reduction in the effective porosity values, lower permeability values and alter the Archie-predicted true resistivity results. However, these effects were compensated for, by the final equations that were used in the evaluations.
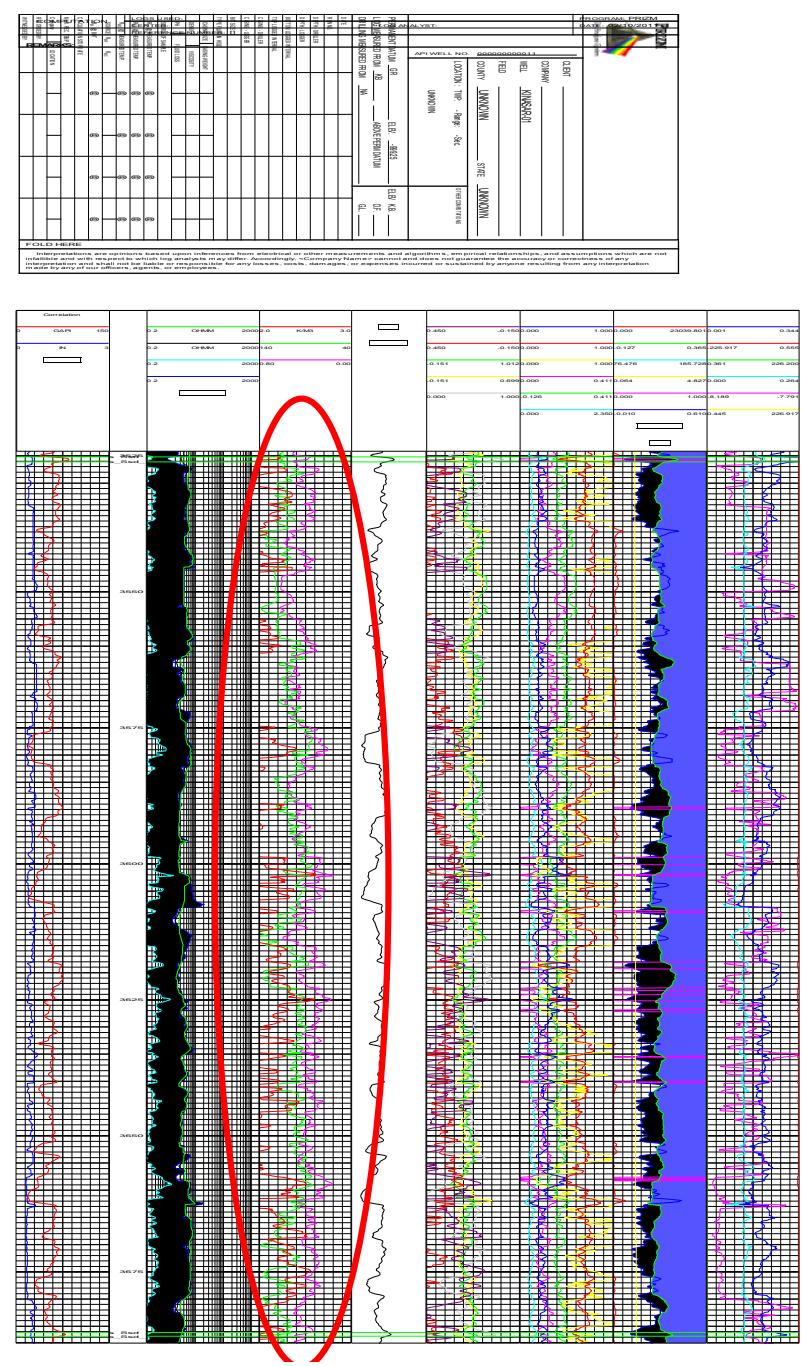

Figure 13: Identified fractures on some of the sand units (sand unit 108 for Ks01). This was done by plotting the bulk density and sonic logs on a compatible porosity scale. 
Citation: Ofoma AE, Chiaghanam OI, Amobi JO, Okogbue CO (2014) Reservoir Characterization of Sand Units Penetrated by Four Wells in the Nigerian Sector of the Chad Basin and its Implication for Hydrocarbon Generation and Accumulation. J Geol Geosci 3: 183. doi:10.4172/23296755.1000183

Page 8 of 9

(3) The bulk volume water (BVW) estimation has shown that the sands of the Basin are fine grained to silty. Porosity versus water saturation plots have shown that some sand units are at irreducible water saturation and some are at semi-irreducible water saturation.

(4) The overall porosities and permeabilities of the sand units of the study wells are within limits that are required for hydrocarbon accumulation and preservation. However, permeability estimations in some sands are poor and excellent in others. Perhaps, the silty nature of most of the sands may probably have contributed to the poor permeability observed in some of the sands. The deeper sand units were observed to have good and better reservoir quality relative to other shallower sand units.

(5) The Archie's water saturation and the modified Simandox water saturation estimations have revealed depths where water is most likely to predominate.

(6) Evidences on hydrocarbon mobility exist in the sands of the study wells. However, the only exception is with the values obtained for ROS. This could be as a result of using the $\mathrm{SN}$ log reading instead of the MSFL reading as input parameter for $\mathrm{RxO}$.
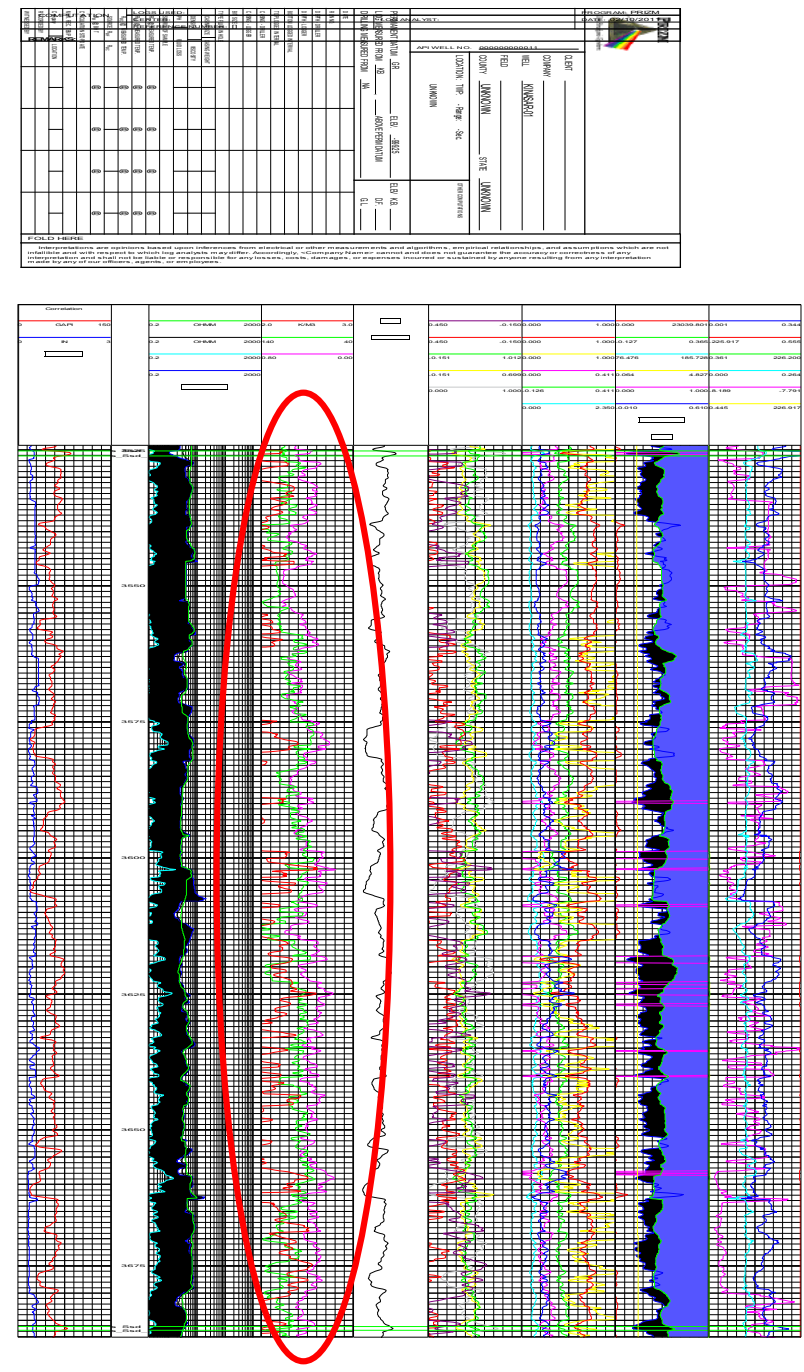

Figure 14: Column plot of Permeability (md) Vs Depths (m) for sand units of the study wells.

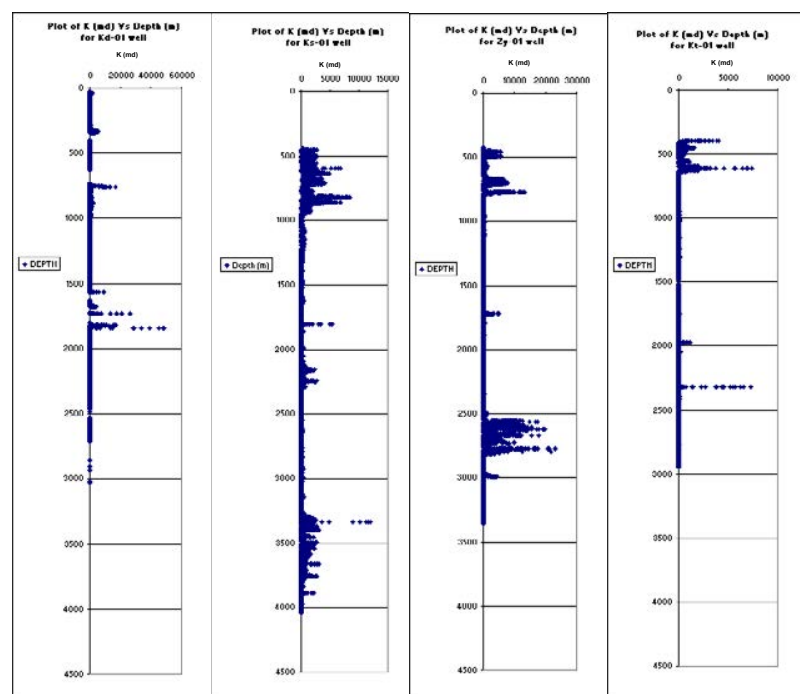

Figure 15: Plots of permeability against depth for all the study wells

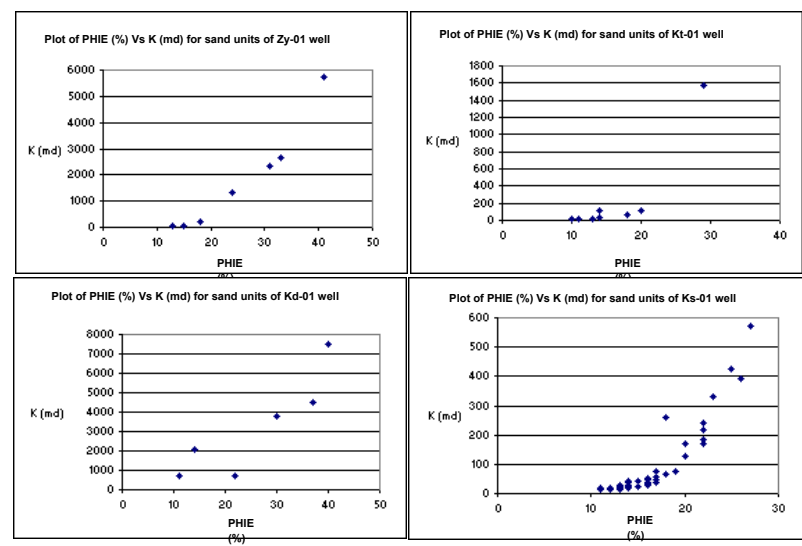

Figure 16: Correlation of wells Ks-01, Kt-01 and Zy-01 using the XSection application of the GeoGraphix software

(7) The correlations between Ks-01, Kt-01 \& Zy-01 wells have revealed that anticlinal structures exist at deeper depths as well as juxtaposed sand bodies. Also thicker sand bodies are observed in Ks-01 well relative to the other wells. There is evidence to show that sand bodies are continuous within the wells, and in some cases these sand bodies tend to die-out before reaching the other well, suggesting probably sand pinchout.

(8) Drilling to deeper depths is strongly recommended due to the very favourable reservoir properties observed at deeper depths for Ks01 and $\mathrm{Zy}-01$ wells. Also the drilling should concentrate within the location of these wells.

\section{Acknowledgments}

The Authors are grateful to the Department of Petroleum Resources (DPR) and the National Petroleum Investment Management Services (NAPIMS) in Nigeria for their kind approval to get requisite data. We appreciate the criticisms, contributions and suggestions from our colleagues during the process of carrying out this study.

\section{References}

1. Obaje NG, Attah DO, Opeloye SA, Moumouni A (2006) Geochemical evaluation 
Citation: Ofoma AE, Chiaghanam OI, Amobi JO, Okogbue CO (2014) Reservoir Characterization of Sand Units Penetrated by Four Wells in the Nigerian Sector of the Chad Basin and its Implication for Hydrocarbon Generation and Accumulation. J Geol Geosci 3: 183. doi:10.4172/23296755.1000183

Page 9 of 9

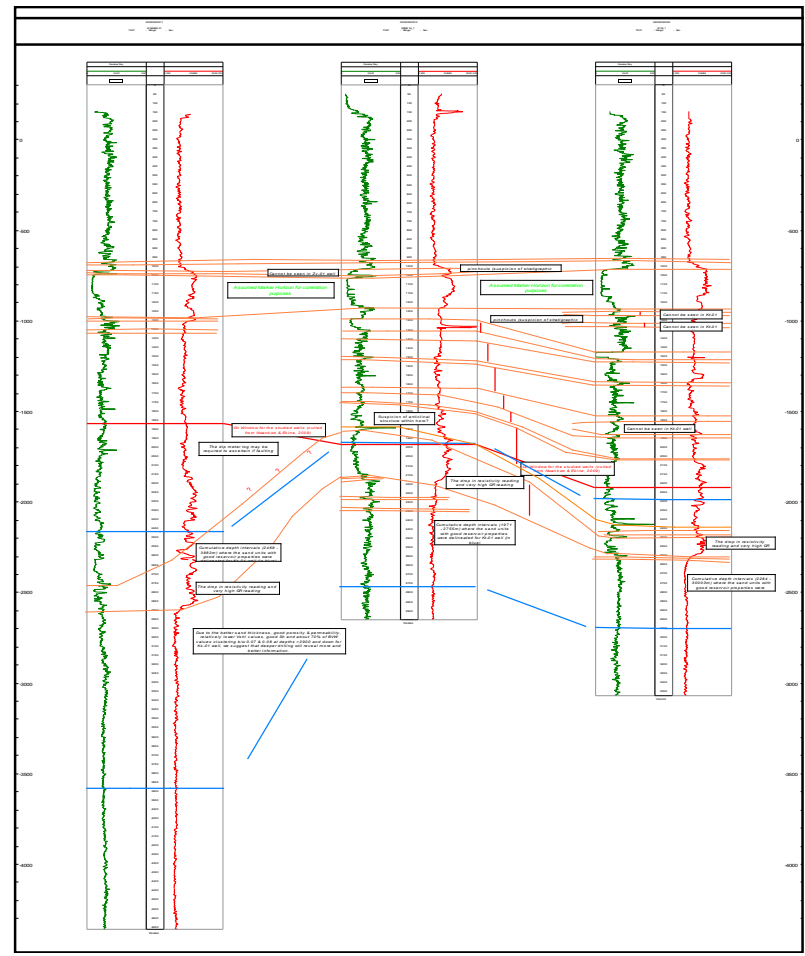

Figure 17: Correlation of wells Ks-01, Kt-01 and Zy-01 using the XSection application of the GeoGraphix software

of the hydrocarbon prospects of sedimentary basins in Northern Nigeria. Geochemical Journal. 40: 227-243.

2. Avbovbo AA, Ayoola EO, Osahon GA (1986) Depositional and structural styles in the Chad Basin of Northeastern Nigeria. AAPG Bull 70: 1787-1798.

3. Olugbemiro RO, Ligouis B, Abaa SI (1997) The Cretaceous series in the Chad Basin, NE Nigeria: source rock potential and thermal maturity. Journal of Petroleum Geology 20: 51-68.

4. Okosun EA (2000) A preliminary assessment of the petroleum potentials from southwest Chad Basin, Nigeria. Bornu Journal of Geology 2: 40-50.

5. Gazali BAT, Zarma AA (2004) Review and assessment of exploration activities in the southwestern Chad Basin, Nigeria. 40th Annual International Conference Nigerian Mining \& Geosciences Society.

6. Christopher IU (2004) Re-evaluation of the petroleum potential of the Bornu Basin, Nigeria. $40^{\text {th }}$ Annual International Conference Nigerian Mining \& Geosciences Society.

7. Nwankwo CN, Ekine AE, Nwosu LI (2009) Estimation of heat flow variation in the Chad Basin Nigeria. Journal of Applied Science \& Environmental Management 13: 73-80.

Citation: Ofoma AE, Chiaghanam OI, Amobi JO, Okogbue CO (2014) Reservoir Characterization of Sand Units Penetrated by Four Wells in the Nigerian Sector of the Chad Basin and its Implication for Hydrocarbon Generation and Accumulation. J Geol Geosci 3: 183. doi:10.4172/2329-6755.1000183
8. Nwankwo CN, Ekine AE (2009) Geothermal gradients in the Chad Basin Nigeria, from bottom hole temperature logs. International Journal of Physical Science 4: 777-783.

9. Ofoma $A E$ (2009) Forecasting the presence of hydrocarbon in the Anambra Basin, Southeastern Nigeria, using Petrophysical Evidence. Unpublished PhD Thesis, University of Nigeria, Nsukka, 321p.

10. Obaje NG (2009) Geology and mineral resources of Nigeria, lecture notes in Earth sciences 120 , springer- verlag berlin Heidelberg.

11. Parker JR (1977) Deep sea sands. In: Hobson GD (ed.), Developments in Petroleum Geology. Applied Sci Pub Barking 225-242.

12. Galloway WF, Hobday DK (1983) Terrigenous clastic depositional systems Applications to petroleum coal and uranium exploration. Springer, Verlag, New York.

13. Hilchie DW (1978) Applied Open-hole log interpretation: Golden, Colorado, DW Hilchie Incorporated, 309p.

14. Simandoux $P$ (1963) Mesures dielectriques en milie poreux, application mesure des saturations en eau: Etude du comportement des Massifs Argileux, Revue de l'institut Francais de Petrole, Supplementary Issue.

15. Ofoma AE, Otoghile C, Okogbue CO, Mamah LI, Amobi JO (2008b) Petrophysical evaluation of Reservoirs: Example from Exploratory wells drilled in the Anambra Basin Southeastern Nigeria. Nigerian Association of Petroleum Explorationist (NAPE) Bulletin 20: 72-81.

16. http://www.pir.sa.gov.au/

17. Dresser A (1982) Well logging and interpretation techniques. The course for home study. Dresser Atlas publication, 121p.

18. Crain ER (1986) The log analysis handbook: Penn well publishing company, Tulsa Oklahoma, 321p.

19. Pettijohn FJ (1975) Sedimentary rocks (3rdedn.) New York, Harper and Row, $628 p$.

20. Wilson JC, McBride EF (1988) Compaction and porosity evaluation of Pliocene sandstones, Ventura Basin California. AAPG Bull 72: 664-681.

21. Ofoma AE, Okogbue CO, Amobi JO, Nwankwoala HO (2008a) Determination of Mineral Composition of Reservoirs using Crossplots and implications on Reservoir Properties: A Case Study of the Cretaceous Reservoirs of the Anambra Basin, Southeastern Nigeria. International Journal of Petroleum Science \& Technology (IJPST) 2: 41-58.

22. Schafer JN (1980) A practical method of well evaluation and acreage development for the naturally fractured Austin Chalk formation. Log Analyst XXI: 10-23.

23. Wichtl FK (1990) Log interpretation seminar (a course designed for modern basic log evaluation practice) Schlumberger international, Houston, Texas.

24. Asquith G, Krygowsky D (2004) Basic well log analysis. AAPG methods in exploration series 16: $244 \mathrm{p}$.

25. Okosun EA (1995) Review of the geology of Bornu Basin. Journal of Mining \& Geology 31: 113-172.

Submit your next manuscript and get advantages of

\section{OMICS Group submissions blishin}

\section{Unique features:}

User friendly/feasible website-translation of your paper to 50 world's leading languages Audio Version of published paper

Digital articles to share and explore

Special features:

400 Open Access Journals

30,000 editorial tea

21 days rapid review process

Quality and quick editorial, review and publication processing

Indexing at PubMed (partial), Scopus, EBSCO, Index Copernicus and Google Scholar etc

Sharing Option: Social Networking Enabled

Authors, Reviewers and Editors rewarded with online Scientific Credits

Better discount for your subsequent articles

Submit your manuscript at: http://www.omicsonline.org/submission 